\title{
UJI EFEK ANTIDIARE KOMBINASI EKSTRAK BIJI PEPAYA (Carica papaya L.) DENGAN DAUN KESUMBA KELING (Bixa orellana L.)PADA MENCIT (Mus musculus)
}

\author{
Novalia Debora*, Wisnu Cahyo Prabowo, Arsyik Ibrahim, Laode Rijai \\ Laboratorium Penelitian dan Pengembangan FARMAKA TROPIS \\ Fakultas Farmasi Universitas Mulawarman, Samarinda, Kalimantan Timur \\ *email: novaliadebora7@gmail.com
}

\begin{abstract}
In traditional medicine papaya seeds can be used as an antibacterial, and to treat indigestion and diarrhea, whereas kesumba keling used to treat stomach and intestinal diseases.. Papaya seeds contain secondary metabolites such as tannins and phenols, whereas in kesumba keling, the leaves also contain tannins, in which both compounds have an antidiarrheal effect. To understand the effect of combination papaya seeds extract (Carica papaya L.) and kesumba keling leaves (Bixa orellana L.) as an antidiarrheal in mice. Mice were divided into five groups, where negative control group were given $C M C$, the positive control group were given loperamide $\mathrm{HCl}$ and three test groups were given the extract with three comparisons of each dose administered orally. Oleum ricini was used as an inducer of diarrhea. Observation shows that combination of kesumba keling leaves : papaya seeds have antidiarrheal effect as at a ratio of 1: 1 and 1: 2
\end{abstract}

Keywords: antidiarrheal, Seeds, Carica papaya L

\begin{abstract}
ABSTRAK
Secara tradisional biji pepaya dapat dimanfaatkan sebagai antibakteri, mengobati gangguan pencernaan dan diare, sedangkan kesumba keling digunakan untuk mengobati penyakit lambung dan usus. Biji pepaya mengandung metabolit sekunder diantaranya tanin dan fenol, sedangkan pada tumbuhan kesumba keling, daunnya juga mengandung tanin, dimana kedua senyawa tersebut memiliki efek sebagai antidiare. Mengetahui efek kombinasi ekstrak biji pepaya (Carica papaya L.) dengan daun kesumba keling (Bixa orellana L.) sebagai antidiare pada mencit. Mencit dikelompokkan menjadi lima kelompok yaitu kelompok kontrol negatif yang diberikan $\mathrm{CMC}$, kelompok kontrol positif yang diberikan Loperamid $\mathrm{HCl}$ dan tiga kelompok uji yang diberikan kombinasi ekstrak dengan tiga perbandingan dosis yang masing-masing diberikan secara oral. Oleum ricini digunakan sebagai penginduksi diare. Pengamatan menunjukkan bahwa kombinasi antara daun kesumba keling : biji pepaya mempunyai efek sebagai antidiare pada perbandingan 1:1 dan 1:2
\end{abstract}

Kata Kunci: Antidiare, Biji, Carica papaya L

\section{PENDAHULUAN}

Diare adalah buang air besar dengan feses yang tidak berbentuk atau cair dengan frekuensi lebih dari 3 kali dalam 24 jam. Diare yang hebat dapat menyebabkan dehidrasi karena tubuh kekurangan cairan, kekurangan kalium, dan elektrolit dalam jumlah yang 
banyak. Dehidrasi berat akan menimbulkan kelemahan, shock bahkan kematian terutama pada anak-anak dan bayi (Nurhalimah, 2015).

Di Indonesia, penyakit diare masih merupakan masalah dibidang kesehatan terutama di daerah pedesaan. Berdasarkan laporan Surveilans Terpadu Penyakit bersumber data KLB (STP KLB) tahun 2010, diare menempati urutan ke-6 frekuensi KLB terbanyak setelah DBD, chikungunya, keracunan makanan, difteri dan campak. (Wahyuni, 2012).

Sesuai dengan organisasi kesehatan dunia (WHO), kurang lebih 3,4 milliar penduduk dalam negara berkembang bergantung pada pengobatan tradisional yang berdasarkan pada tanaman. Hal ini menggambarkan bahwa $88 \%$ penduduk dunia yang menyandarkan pada pengobatan tradisional untuk kelangsungan kesehatan primernya (Sarker dan Lutfun, 2007).

Menurut Palombo (2006) tingginya angka kejadian diare akut dan kronis serta efek samping obat antidiare yang ada saat ini, mendorong para peneliti untuk terus berusaha dalam menemukan obat sebagai antidiare baru, terutama yang berasal dari tanaman. Beberapa penelitian telah membuktikan khasiat tanaman obat tradisional sebagai antidiare, yaitu dengan cara melihat efek biologis ekstrak tanaman yang mempunyai aktivitas sebagai antipasmodik, penunda transit intestinal, menekan motilitas usus, merangsang absorpsi air dan mengurangis sekresi elektrolit.

Tidak semua tanaman dapat dijadikan ramuan obat tradisional untuk mengobati diare. Hal ini dikarenakan berbedanya kandungan metabolit sekunder pada masing-masing tanaman. Beberapa tumbuhan yang dapat berfungsi sebagai obat diare adalah pepaya dan kesumba keling.

Salah satu tanaman yang dapat dimanfaatkan sebagai obat tradisional adalah tanaman pepaya (Carica papaya L.). Secara tradisional biji pepaya dapat dimanfaatkan sebagai antibakteri karena biji pepaya diketahui mengandung senyawa kimia seperti golongan fenol, alkaloid dan saponin. Selain itu biji pepaya juga bermanfaat untuk obat cacing gelang, gangguan pencernaan, diare, dan penyakit kulit (Warisno, 2003).

Selain itu tanaman lain adalah daun kesumba keling (Bixa orellana L.) memiliki manfaat untuk mengobati diare dan perut kembung. Cara untuk mengelolah kesumba keling sebagai obat diare adalah daun kesumba keling sepetrtiga genggaman dicuci lalu direbus dengan 2 gelas air. Setelah dingin disaring kemudian ditambahkan madu (Darwis, 2012).

Menurut Gelmy (2014) kesumba keling juga digunakan dalam obat tradisional untuk mengobati penyakit jantung, lambung dan usus, serta masalah pernapasan dan luka bakar.

\section{METODE PENELITIAN}

\section{Alat dan Bahan}

Alat yang digunakan meliputi mortar, stamper, timbangan analitik, timbangan hewan, sonde, alat ekstraksi pemekatan, penggaris, stopwatch, water bath, alat-alat kaca dan penangas. Bahan yang digunakan yaitu biji pepaya, daun kesumba keling, etanol 96\%, kertas saring.

\section{Prosedur Kerja}

Sampel biji pepaya dan daun kesumba keling dibuat menjadi simplisia kemudian diekstraksi dengan menggunakan pelarut etanol $96 \%$. Selanjutnya dilakukan pengujian aktivitas antidiare dari kombinasi ekstrak etanol biji pepaya dan daun kesumba keling 
dengan cara hewan uji dikelompokkan menjadi lima kelompok yaitu kelompok kontrol negatif yang diberikan $\mathrm{CMC}$, kelompok kontrol positif yang diberikan Loperamid $\mathrm{HCl}$ dan tiga kelompok uji yang diberikan ekstrak dengan tiga perbandingan dosis yaitu 1:1;1:2 dan $2: 1$, dimana dosis yang digunakan untuk daun kesumba keling adalah 54,6 mg/20 g BB dan dosis yang digunakan untuk biji pepaya adalah $16 \mathrm{mg} / 20 \mathrm{~g}$ BB yang masing-masing diberikan secara oral. Oleum ricini digunakan sebagai penginduksi diare.

\section{HASIL DAN PEMBAHASAN}

Tabel 1. Total waktu terjadi diare, frekuensi diare, total diameter serapan air.

\begin{tabular}{cccc}
\hline Dosis uji & $\begin{array}{c}\text { Total Waktu } \\
\text { Diare (menit) }\end{array}$ & Frekuensi Diare & $\begin{array}{c}\text { Total Diameter } \\
\text { serapan (cm) }\end{array}$ \\
\hline CMC & 370 & $13 \mathrm{kali}$ & 7,2 \\
Loperamid $\mathrm{HCl}$ & 130 & $7 \mathrm{kali}$ & 9,5 \\
Kombinasi 1:1 & 136 & $6 \mathrm{kali}$ & 2,4 \\
Kombinasi 1:2 & 142 & $6 \mathrm{kali}$ & 3,3 \\
Kombinasi 2:1 & 332 & $12 \mathrm{kali}$ & 11 \\
\hline
\end{tabular}

Pengujian efek antidire dilakukan dengan menggunakan hewan coba yaitu mencit (Mus muculus). Mencit dibiarkan selama 2 minggu agar dapat beradaptasi dengan lingkungan pengujian. Pengujian efek antidiare ekstrak biji pepaya dan daun kesumba keling menggunakan perbandingan dosis (kesumba keling : biji pepaya) 1:1 , 1:2 dan 2:1, dimana dosis yang digunakan untuk daun kesumba keling adalah $54,6 \mathrm{mg} / 20 \mathrm{~g}$ BB dan dosis yang digunakan untuk biji pepaya adalah $16 \mathrm{mg} / 20 \mathrm{~g}$ BB. Dilakukan kombinasi agar diharapkan mendapatkan efek yang lebih baik dibandingkan dengan dosis tunggal.

Sebelum diuji mencit dipuasakan terlebih dahulu selama 30 menit tujuannya yaitu agar kondisi di dalam lambung dan saluran pencernaan mencit kosong, sehingga oleum ricini dapat bekerja lebih cepat. Penentuan efek antidiare dilakukan dengan cara mengamati waktu terjadinya diare, frekuensi diare, dan diameter serapan air.

Pengamatan waktu terjadinya diare dilakukan dengan cara mengamati waktu awal terjadinya diare yang ditandai dengan konsistensi feses yang berair, hingga berhentinya diare yang ditandai feses normal. Hal ini bertujuan untuk mengetahui berapa lama waktu yang di perlukan ekstrak untuk mengobati diare yang dibandingkan dengan kontrol positif dan kontrol negatif.

Tabel diatas menunjukkan bahwa semakin kecil nilai total rentang waktu diare maka semakin kuat efek antidiare yang diberikan. Kelompok kontrol positif mempunyai nilai rentang waktu lebih kecil dibandingkan kelompok perlakuan yang lain. Sifat Loperamid $\mathrm{HCl}$ bekerja langsung pada otot sirkuler dengan menurunkan prostaglandin, aktivitas otot sirkuler secara serentak diturunkan dan mengaktivasi reseptor pada usus halus dan meningkatkan kontraksi segmen sehingga waktu lintas usus dapat diperlambat dan waktu untuk absorpsi air dapat lebih banyak. Kontrol negatif mempunyai total rentang waktu lebih lama yaitu 370 menit karena pada kelompok ini mencit yang telah mengalami diare hanya diberikan CMC, dimana CMC tidak dapat menyembuhkan diare.

Dosis kombinasi 1:1 mempunyai nilai total rentang waktu sebesar 136 menit, sementara pada dosis kombinasi 1:2 mempunyai nilai lebih lama dibandingkan dengan dosis 1:1 yaitu 142 menit, dan pada dosis kombinasi 2:1 memiliki waktu yang paling lama dibandingkan kedua dosis lainnya yaitu 332 menit. Jadi, dari tabel diatas menunjukkan 
bahwa pada dosis kombinasi 1:1 memiliki rentang waktu yang paling singkat diantara dosis kombinasi lainnya.

Diare ditandai dengan buang air besar dimana frekuensinya meningkat dari keadaan normal. Tabel diatas menunjukkan bahwa semakin sedikit frekuensi diare yang terjadi maka semakin kuat efek antidiare yang diberikan. Kontrol negatif memiliki frekuensi diare yang paling banyak yaitu sebanyak 13 kali, hal ini disebabkan karena CMC tidak dapat menyembuhkan diare. Sementara dosis kombinasi 1:1 dan 1:2 mempunyai nilai frekuensi yang sama dan lebih sedikit dibandingkan dengan kontrol positif, sedangkan dosis kombinasi 2:1 memiliki frekuensi paling banyak diantara dosis kombinasi lainnya dan hampir sebanding dengan kontrol negatif.

Penentuan diameter serapan air dapat dilihat pula untuk mengetahui konsistensi feses. Dimana semakin besar diameter serapan airnya maka konsistensi fesesnya semakin cair. Tabel diatas menunjukkan bahwa dosis kombinasi 1:1 memiliki nilai lebih kecil dibandingkan dengan dosis kombinasi 1:2, dan keduanya memiliki nilai yang lebih kecil dibandingkan dengan kontrol positif yaitu loperamid $\mathrm{HCl}$. Sedangkan pada dosis kombinasi 2:1 memiliki nilai yang lebih besar dari kontrol negatif yaitu CMC. Semakin kecil nilai diameter serapan airnya maka semakin kuat efek antidiare yang diberikan.

Pengukuran total diameter serapan air dilakukan dari awal terjadinya diare yang ditandai dengan feses cair hingga berhentinya diare yang ditandai dengan feses normal. Banyaknya pengeluaran air pada saat terjadi diare disebabkan karena peristaltik usus membantu mendorong cairan yang berlebih menuju usus besar. Dalam kolon akan terjadi penyerapan cairan dan apabila kapasitas cairan melebihi kapasitas penyerapan maka cairan akan keluar bersama, sehingga banyak cairan yang keluar.

Menurut Purwaningdyah (2015), biji pepaya mempunyai efek sebagai antidiare dengan dosis terbaik $800 \mathrm{mg} / \mathrm{kgBB}$, tetapi dosis tersebut tidak memiliki potensi yang sebanding dengan loperamid $\mathrm{HCl}$. Menurut Laning (2008) kesumba keling memiliki efek antidiare, dimana hasilnya memiliki perbedaan bermakna yaitu dengan menurangi waktu terjadinya diare, mengurangi bobot feses dan memperbaiki konsistensi feses dari lembekcair menjadi normal-padat tetapi tidak menunjukkan korelasi antara dosis dan efek.

Kombinasi antara daun kesumba keling dengan biji pepaya dapat meningkatkan aktivitas antidiare dibandingkan dengan dosis tunggal.

\section{KESIMPULAN}

Dosis kombinasi antara daun kesumba keling : biji pepaya mempunyai efek sebagai antidiare pada perbandingan 1:1 dan 1:2 serta mempunyai potensi yang sebanding dengan loperamid $\mathrm{HCl}$.

\section{DAFTAR PUSTAKA}

Dalimartha, S. 2009. Atlas Tumbuhan Obat Indonesia jilid 6. Pustaka Bunda. Jakarta

Darwis, Welly. 2012. Tanaman Obat yang terdapat di Kota Bengkulu yang Berpotensi sebagai Obat Penyakit dan Gangguan pada Sistem Pencernaan Manusia. Jurnal Ilmiah Konservasi Hayati. Vol. 08 No. 01

Gelmy L. Ciro1, Jose E. Zapata and Jessica Lopez. 2014. Evaluasi In Vitro dari Biji Bixa orellana L. ( Annatto ) Sebagai Potensi Pengawet Makanan Alam. Journal of Medicinal Plant Research. Vol. 8 No. 21

Laning, Meri Yanti N. 2008. Uji efek antidiare dari esktrak daun kesumba keling (Bixa orellana, Linn) pada tikus jantan dewasa. Widya Mandala Catholic University Surabaya. 
Nurhalimah, Hanny., Novita Wijayanti., Tri Dewanti Widyaningsih. 2015. Efek Antidiare Ekstrak Daun Beluntas (pluchea indica L.) Terhadap Mencit Jantan yang Diinduksi Bakteri Salmonella thypimurium. Jurnal Pangan dan Agroindustri Vol. 3 No 3

Palombo, E.A. 2006. Fitokimia dari Tradisional Tanaman Obat Digunakan dalam Pengobatan Diare : Mode Aksi dan Efek pada fungsi usus. Farmakoterapi Research. 20(9)

Purwaningdyah, Yunia Galih., Tri Dewanti Widyaningsih., Novita Wijayanti. 2015. Efektivitas Ekstrak Biji Pepaya (Carica papaya L.) sebagai Antidiare pada Mencit yang Diinduksi Salmonella typhimurium. Jurnal Pangan dan Agroindustri Vol. 3 No 4

Sarker, Styajit D., Lutfun, Nahar. 2007. Kimia untuk Mahasiswa Farmasi Umum, Organik dan Produk Alam Kimia. Inggris.

Wahyuni, Tri., Saeful Hidayat.,Tedjo Narko. 2012. Uji Aktivitas Antidiare Ekstrak Etanol Biji Teratai Putih (Nymphaea pubescens willd) terhadap Mencit dengan Metode Transit Intestinal. Indonesian Journal of Pharmaceutical Science and Technology Vol.1, No.2

Warisno. 2003. Budidaya Pepaya. Kanisius. Yogyakarta 